\title{
Model Motivasi Trisula: Sintesis Baru Teori Motivasi Berprestasi
}

\author{
Edy Purwanto ${ }^{1}$ \\ Jurusan Psikologi Universitas Negeri Semarang
}

\begin{abstract}
The purpose of this study was to find out a comprehensive model of achievement motivation appropriate for Indonesian students. Specifically, this study examined the contribution of task-value, self-efficacy and goal orientation in influencing students' achievement motivation. The subjects of this research were 393 high school students, 219 of them are female and 174 are male. $46 \%$ of them were senior high school and $54 \%$ junior, high school students. $45 \%$ were from public schools and 55\% from religion-based private schools. The task-value, self-efficacy, goal orientation and achievement motivation as scaling instruments used in this study were developed from Motivated Strategies for Learning Questionnaire Manual. The instruments had been tested and proved valid and reliable. Analysis of model testing data was done using technique of confirmatory factor analysis. The results showed that the trisula model of achievement motivation was reliable. The task-value, self-efficacy and goal orientation are significant loading factors for achievement motivation. The self-efficacy also is a significant loading factor for the task-value and goal orientation.

Keywords: achievement motivation, goal orientation, self-efficacy, task-value
\end{abstract}

Abstrak. Penelitian ini bertujuan menemukan model motivasi berprestasi yang komprehensif dan cocok untuk siswa Indonesia. Secara spesifik, penelitian menguji kontribusi tiga elemen esensial pembentuk motivasi berprestasi: nilai-tugas, efikasi-diri, dan orientasi tujuan. Subjek penelitian ini adalah 393 orang siswa, terdiri atas 219 perempuan dan 174 laki-laki, 46\% siswa SMA dan 54\% siswa SMP, 45\% siswa dari sekolah negeri dan 55\% siswa sekolah swasta berbasis agama. Instrumen pengumpulan data yang digunakan dalam penelitian ini berupa skala nilai-tugas, skala efikasi-diri, skala orientasi tujuan, dan skala motivasi berprestasi yang digunakan dalam penelitian ini dikembangkan dari Motivated Strategies for Learning Questionaire Manual. Sebelum digunakan, instrumen tersebut telah diuji dan terbukti valid serta reliabel. Analisis data pengujian model dilakukan dengan teknik analisis faktor konfirmatori. Hasil penelitian menunjukkan bahwa model trisula motivasi berprestasi merupakan model yang andal. Nilai-tugas, efikasi-diri, dan orientasi tujuan, memiliki faktor loading signifikan terhadap motivasi berprestasi. Efikasi-diri juga memiliki faktor loading signifikan terhadap nilai-tugas dan orientasi tujuan.

Kata kunci: efikasi-diri, nilai-tugas, motivasi berprestasi, orientasi tujuan

Sebagian siswa di Indonesia telah mampu mengembangkan motivasi yang tinggi. Mereka terbiasa mengatur aktivitas belajarnya secara disiplin, senang bersibuk-diri dalam berbagai aktivitas akademik, terlibat dalam berbagai ajang kompe-

\footnotetext{
${ }^{1}$ Korespondensi mengenai isi artikel ini dapat dilakukan melalui: edy.purwanto21@yahoo.com
}

tisi akademik seperti lomba karya ilmiah, olimpiade fisika, olimpiade matematika, dan semacamnya. Namun secara keseluruhan, motivasi berprestasi siswa umumnya masih rendah. Sangat banyak dijumpai siswa yang ingin memperoleh nilai rapor bagus, lulus ujian dan masuk perguruan tinggi tetapi usaha belajarnya tidak serius, tidak memiliki kebiasaan belajar 
yang teratur, mudah bosan ketika melakukan belajar. Kondisi rendahnya motivasi itu membawa akibat pada rendahnya kompetensi yang dikuasai siswa, yang pada gilirannya mengundang munculnya praktik-praktik curang dalam ujian. Fenomena ini mengungkapkan kegagalan guru di berbagai satuan pendidikan dalam mengembangkan motivasi berprestasi siswa. Sumber permasalahan bukan karena tidak adanya teori motivasi hebat melainkan kesulitan para guru untuk memilih teori motivasi apa saja yang perlu diterapkan secara terpadu untuk mengembangkan motivasi siswa.

Hingga saat ini, banyak teori motivasi berprestasi yang dikembangkan oleh para ahli. Namun belum ada satupun teori yang komprehensif yang dapat diterapkan guru guna meningkatkan motivasi berprestasi siswa dengan hasil yang memuaskan. Untuk menghasilkan peningkatan motivasi berprestasi yang lebih kuat, guru harus mengkombinasikan penerapan beberapa teori motivasi berprestasi. Persoalan yang muncul kemudian adalah bahwa masing-masing teori motivasi yang telah ada pada umumnya memfokuskan pada salah satu elemen atau faktor motivasi, dan tidak jarang ditemui bahwa suatu teori membuat asumsi meta-teori sendiri-sendiri serta memunculkan istilahistilah yang berbeda untuk sebuah konstrak psikologis yang sama. Sebagai contoh, dalam beberapa literatur motivasi dijumpai bahwa konstrak harapan dikonseptualisasikan dengan beragam istilah. Ada ahli yang menyebutnya sebagai perceived control, self-efficacy, attribution style, dan control belief, padahal konstrak dasarnya (the basic construct) dari sejumlah atribut psikologis tersebut adalah sama yaitu mencakup keyakinan akan kemampuan mereka untuk mengerjakan suatu tugas (Pintrich \& De Groot, 1990). Munculnya istilah-istilah yang tumpang-tindih satu dengan yang lain tentu menimbulkan kesulitan bagi guru ketika harus menerapkan lebih dari satu teori guna mendapatkan efek peningkatan motivasi berprestasi yang lebih kuat. Oleh karena itu teori-teori motivasi berprestasi yang ada perlu dianalisis dan selanjutnya disintesiskan ke dalam sebuah model motivasi berprestasi yang bersifat komprehensif, yakni sebuah model motivasi berprestasi yang mengakomodasi elemen-elemen esensial motivasi berprestasi

Schunk, Pintrich, dan Meece (2008) mengajukan definisi motivasi sebagai "proses di mana aktivitas yang terarah pada suatu tujuan tertentu didorong dan dipertahankan." Motivasi berprestasi atau motivasi untuk berprestasi dengan demikian adalah motivasi yang tujuannya adalah meraih prestasi. Definisi tersebut sejalan dengan yang diajukan Nicholl (1984) bahwa motivasi berprestasi adalah motivasi yang ditujukan untuk mengembangkan ataupun mendemonstrasikan kemampuan yang tinggi. Seseorang dikatakan berprestasi jika ia berhasil mengembangkan atau mendemonstrasikan kemampuan yang tinggi. Singkatnya, motivasi berprestasi adalah motivasi yang bertujuan untuk mengejar prestasi yaitu untuk mengembangkan ataupun mendemonstrasikan kemampuan yang tinggi.

\section{Indikator Motivasi Berprestasi}

Schunk, dkk. (2008); Wigfield dan Eccles, (2002) mengemukakan bahwa indikator dari motivasi berprestasi, khususnya dalam setting akademik, meliputi, (1) Choice atau memilih terlibat dalam tugas akademik daripada tugas-tugas non-akademik. Perilaku memilih tugas prestasi ini misalnya memilih mengerjakan tugas sekolah daripada menonton TV, menelepon teman, bermain game, ataupun aktivi- 
tas-aktivitas lainnya yang dapat dipilih untuk mengisi waktu luang; (2) Persistence atau persisten (ulet) dalam tugas prestasi, terutama pada waktu menghadapi rintangan seperti kesulitan, kebosanan, ataupun kelelahan; dan (3) Effort atau mengerahkan usaha baik berupa usaha secara fisik maupun usaha secara kognitif seperti misalnya menerapkan strategi kognitif ataupun strategi metakognitif. Perilaku yang mencerminkan usaha ini misalnya berupa mengajukan pertanyaan yang bagus ketika di kelas, mendiskusikan materi pelajaran dengan teman sekelas atau teman lain di luar jam sekolah, memikirkan secara mendalam meteri pelajaran yang sedang dipelajari, menggunakan waktu yang memadai untuk mempersiapkan ujian, merencanakan aktivitas belajar, menerapkan mnemonic dalam belajar.

Identifikasi elemen-elemen esensial motivasi berprestasi

Masing-masing teori motivasi berprestasi berbeda dalam menjelaskan elemen atau komponen yang menyebabkan tinggi/rendahnya motivasi berprestasi. Muncul sejumlah konstrak berbeda yang diajukan oleh masing-masing ahli terkait pertanyaan: "Mengapa beberapa siswa mampu tetap persisten dalam mengerjakan suatu tugas atau aktivitas akademik yang penuh tantangan sementara siswasiswa yang lain cepat sekali menyerah dalam tugas tersebut meski mereka memiliki kemampuan untuk mengerjakan tugas tersebut?" Hasil analisis terhadap sejumlah teori motivasi berprestasi ditemukan tiga elemen esensial yaitu efikasi diri, nilai-tugas, dan orientasi tujuan.

\section{Efikasi Diri}

Efikasi-diri menunjuk pada keyakinan individu atas kapabilitas yang dimilikinya untuk mengerjakan tugas yang dihadapi. Bandura (1997) mengemukakan bahwa perilaku orang diarahkan oleh keyakinannya tentang seberapa tinggi peluang untuk sukses dalam mengerjakan suatu tugas, yang dinamakan efikasi-diri. Untuk berhasil dalam mengerjakan suatu tugas, selain dituntut memiliki pengetahuan dan keterampilan untuk mengerjakan tugas secara berhasil, orang juga harus memiliki keyakinan bahwa sukses akan berhasil diraih. Siswa dengan efikasi-diri tinggi dalam matapelajaran yang diikuti, memperlihatkan perjuangan yang gigih untuk meraih sukses. Sebaliknya siswa dengan efikasi diri-rendah cenderung menghindari tugas-tugas akademik, persistensinya dalam berusaha rendah, ketika menghadapi kesulitan mudah menyerah (Pajares, 2003; Schunk, 1981).

Sejumlah konstrak psikologi yang secara substansial memiliki makna serupa dengan efikasi-diri. meliputi harapan untuk sukses, keyakinan kontrol (control belief), gaya atribusi, dan sebagainya. Penelitian yang dilakukan Kirsh (1985) menemukan bahwa konstrak efikasi-diri dan harapan mempunyai substansi yang sama. Kirsh memberi judul artikel yang ditulisnya dalam Journal of Social Psychology dengan "efikasi-diri dan harapan, anggur lama dengan label baru." Konstrak gaya atribusi yang diajukan Weiner (1992) secara substansial berkesesuaian dengan konstrak efikasi-diri. Bahwa gaya atribusi individu yang memandang sukses yang diraihnya disebabkan oleh faktor kemampuan dirinya dan usaha yang dikerahkan, sedang gagal diatribusikan pada kurang beruntung atau kurang usaha, pada hakekatnya merupakan pengejawantahan dari individu dengan efikasi-diri tinggi. Sebaliknya individu yang mengatribusikan sukses kepada faktor eksternal seperti keberuntungan dan mengatribusikan ga- 
gal kepada kurangnya kemampuan, merupakan pengejawantahan dari individu dengan efikasi-diri rendah.

Dalam konteks pendidikan, efikasidiri terdiri ada dua aspek: (1) Efikasi-diri akademik, sebuah penilaian diri seorang individu atas kemampuannya untuk sukses dalam mencapai tujuan-tujuan akademik; dan (2) Efikasi-diri untuk regulasidiri, sebuah penilaian diri seorang individu akan kemampuan dirinya untuk mengatur kognisi, afeksi, dan tindakan guna meraih sukses akademik.

\section{Nilai-tugas}

Ketika individu dihadapkan pada suatu tugas, salah satu pertanyaan yang muncul dalam benaknya adalah mengapa saya mau mengerjakan tugas ini. Jawaban atas pertanyaan tersebut berkaitan dengan nilai atau harga dari tugas yang dikerjakan tersebut bagi individu. Konstrak psikologi yang diajukan oleh para peneliti terkait konsep nilai-tugas meliputi nilai atau motivasi intrinsik, nilai ekstrinsik atau nilai guna atau motivasi ekstrinsik. Satu lagi nilai yang penting bagi orang Indonesia yaitu nilai spiritual, yaitu nilai yang berkaitan dengan penghayatan dirinya sebagai makhluk religius.

Eccles (1983); Wigfield dan Eccles, (1992) mendefinisikan nilai-tugas secara operasional dalam; attainment value, intrinsic motivasit, dan utility value atau extrinsic value. Maksudnya, keyakinan tentang nilai yang diletakkan siswa terhadap suatu tugas akan meningkat seiring dengan meningkatnya keyakinannya bahwa tugas akademik itu penting baginya (attainment value), menyenangkan untuk dilakukan (intrinsicmotivasit), memiliki kegunaan atau manfaat bagi dirinya (utility value).

Nilai tugas juga dapat terbangun melalui pengalaman sukses serta keakraban dengan tugas. Bandura dan Schunk (1981) melaporkan bahwa keberhasilan mencapai standar yang menjadi tujuan dalam suatu tugas menghasilkan efek meningkatknya motivasi intrisik terhadap tugas tersebut. Tobias (1995) dalam penelitiannya menemukan bahwa semakin akrab terhadap suatu materi pelajaran (prior knowledge) akan semakin tinggi motivasi intrinsik siswa terhadap pelajaran tersebut. Untuk menguasai suatu materi baru seringkali dibutuhkan penguasaan atas materi-materi yang berada pada tingkat di bawahnya. Oleh karena itu untuk mempercepat tumbuhnya motivasi terutama pada tahap awal, dapat ditempuh melalui rancangan pembelajaran yang mengkaitkan antara materi pelajaran dengan minat siswa, sebagai contoh, dalam pembelajaran bahasa Inggris, dapat dilakukan dengan mendayagunakan musik yang berbahasa Inggris.

Tentang seberapa tinggi individu memandang penting terhadap suatu tugas, biasanya berkaitan dengan nilai-nilai religi atau budaya yang telah dihayatinya. Bell dan Smith (2003) menyebutnya sebagai motivasi personal bersumber religi. Penelitian Purwanto dan Sutoyo (2007) menemukan bahwa pemberian intervensi berupa internalisasi nilai-nilai spiritual-qur'ani merupakan sumber motivasi yang kuat bagi motivasi berprestasi siswa. Siswa yang menemukan adanya nilai spiritual dari serangkaian aktivitas akademik yang dilakukan, menunjukkan persistensi yang lebih tinggi dalam belajar.

Singkatnya, elemen nilai-tugas terdiri atas tiga aspek: (1) nilai guna atau nilai ekstrinsik, ada reward atau benefit yang bakal diperoleh individu melalui serangkaian aktivitas yang dilakukan individu dalam suatu tugas. Dengan kata lain serangkaian tindakan yang dilakukan individu merupakan instrumen atau alat untuk memperoleh sesuatu yang bernilai 
bagi individu; (2) nilai intrinsik, ada keingintahuan (curiosity) yang hendak dicaritahu jawabnya melalui tugas yang dikerjakan, ada perasaan senang (enjoy) yang diperoleh melalui serangkaian aktivitas yang dikerjakan, ada kompetensi tertentu yang hendak dikuasai melalui serangkaian aktivitas yang dilakukan; dan (3) nilai spiritual. Melalui serangkaian aktivitas yang dilakukan individu yakin akan memperoleh benefit spiritual (keberkahan, kasih sayang) dari Tuhan.

\section{Orientasi tujuan}

Orientasi tujuan berkaitan dengan tujuan atau sasaran yang hendak dicapai individu dalam suatu tugas. Terem atau konstrak psikologi yang diajukan para peneliti terkait orientasi tujuan meliputi tujuan masteri (mastery goal orientation), tujuan performansi (performance goal orientation). Penerapan konsep tersebut berupa goal-setting. Locke dan Latham (1990) melaporkan temuan penelitian bahwa pemilihan suatu tujuan dan komitmen terhadap tujuan yang terkait dengan suatu tugas dipengaruhi oleh efikasi-diri dalam tugas tersebut.
Elemen orientasi tujuan terdiri atas dua aspek yaitu: (1) Tujuan masteri, individu memiliki tujuan yang jelas serta komitmen yang tinggi untuk menguasai atau memperbaiki kompetensi tertentu, untuk mengembangkan keterampilan atau kecakapan baru melalui tugas-tugas akademik yang dilakukan. (2) Tujuan performansi, individu memiliki tujuan yang jelas serta komitmen yang tinggi untuk mengungguli performansi orang lain, untuk memperoleh pengakuan publik atas sukses yang dicapai. Aspek tujuan menghindari performansi (performance-avoid goal), yaitu bertujuan menghindari penilaian tidak kompeten, tidak dimasukkan sebagai aspek tersendiri dari orientasi tujuan, sebab performansi merupakan pola maladaptive dari tujuan performansi. Individu yang memiliki tujuan menghindari performansi, orientasinya ketika menghadapi tugas prestasi adalah agar tergolong dalam kelompok kompetensi rendah. Model utuh model trisula motivasi berprestasi dapat dilihat pada Gambar 1.

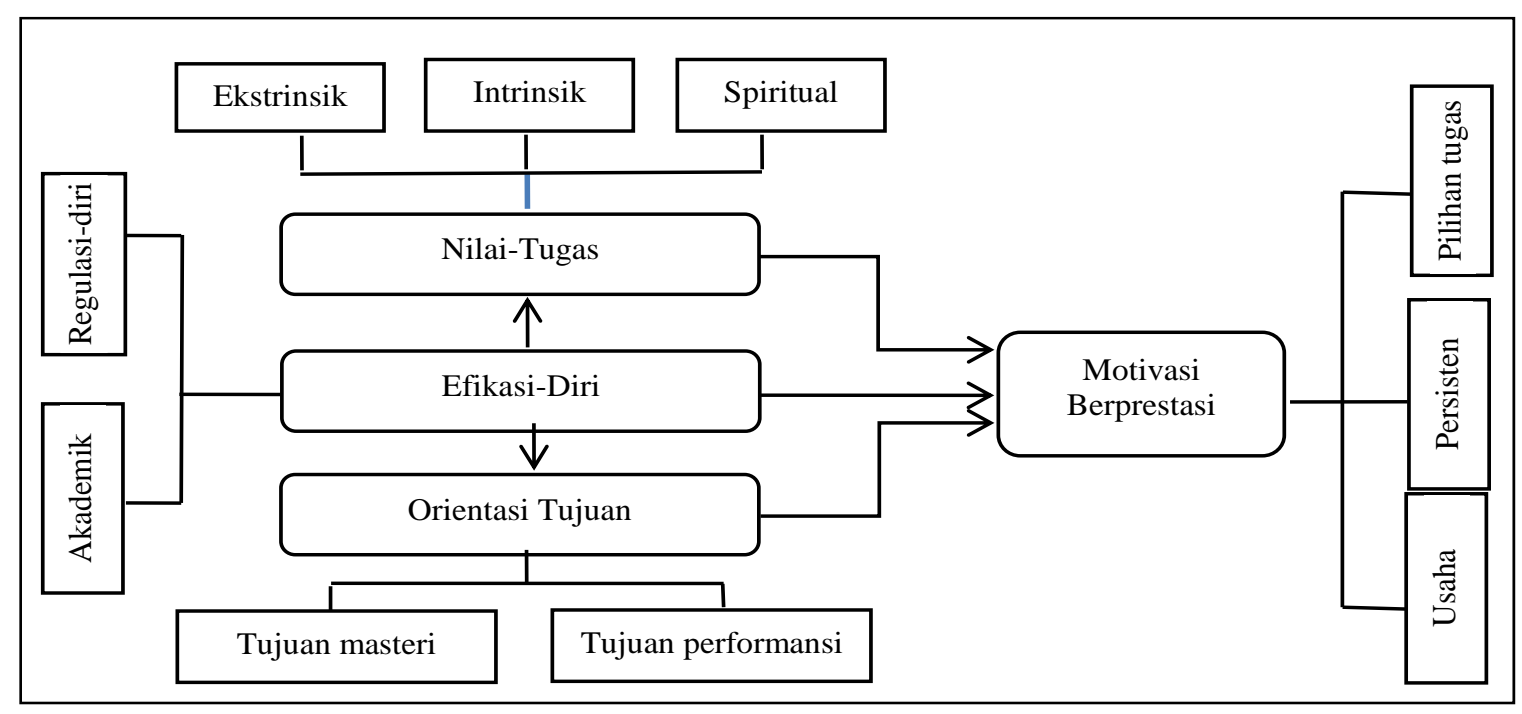

Gambar 1. Model Trisula Motivasi Berprestasi 


\section{Metode}

Subjek penelitian ini adalah 393 orang siswa, terdiri atas 219 perempuan dan 174 laki-laki, $46 \%$ siswa SMA dan 54\% siswa SMP, $45 \%$ siswa dari sekolah negeri dan $55 \%$ siswa sekolah swasta berbasis agama. Skala nilai-tugas, skala efikasi-diri, skala orientasi tujuan, dan skala motivasi berprestasi yang digunakan dalam penelitian ini dikembangkan dari Motivated Strategies for Learning Questionaire Manual (MSLQM) yang disusun oleh Pintrich, Smith, Garcia, dan McKeachie (2006). Hasil analisis faktor konfirmatori dan uji reliabilitas alfa dengan SPSS for Windows versi 20 menunjukkan bahwa skala efikasi-diri, indeks validitas bergerak antara 0.412 sampai dengan 0.849 dan reliabilitas alfa sebesar 0.836. Skala nilai-tugas, indeks validitas bergerak antara 0.535 sampai dengan 0.780, dan reliabilitas 0.794 . Skala orientasi tujuan, validitas 0.808 sampai dengan 0.887, dan reliabilitas 0.895. Untuk skala motivasi berprestasi, indeks validitas antara 0.488 sampai dengan 0.705 , dengan reliabilitas 0.761 . Analisis data pengujian model dilakukan dengan bantuan Program Lisrel versi 8.51 .

\section{H a s i 1}

Data hasil analisis menunjukan bahwa sejumlah besar kriteria model fit $(\mathrm{RMSEA}=0.053 ; \mathrm{NFI}=0.97 ; \mathrm{GFI}=0,97>0,90$; ECVI for Saturated Model $=0.28<$ for Independence Model $=3.82 ; \quad \mathrm{NFI}=0,96>0,90$ ) terpenuhi. Itu berarti bahwa model fit, artinya tidak terdapat perbedaan yang signifikan antara matrik kovarian dari model teoritik dengan matrik kovarian data. Dengan demikian dapat disimpulkan bahwa model teoritik yang terdiri atas nilai-tugas, efikasi-diri, orientasi tujuan sesuai untuk menjelaskan tinggi-rendahnya tingkat motivasi berprestasi siswa.

Gambar 2 adalah gambar koefisien jalur hasil analisis persamaan struktural antar variabel model trisula motivasi berprestasi dengan menggunakan metode LISREL.

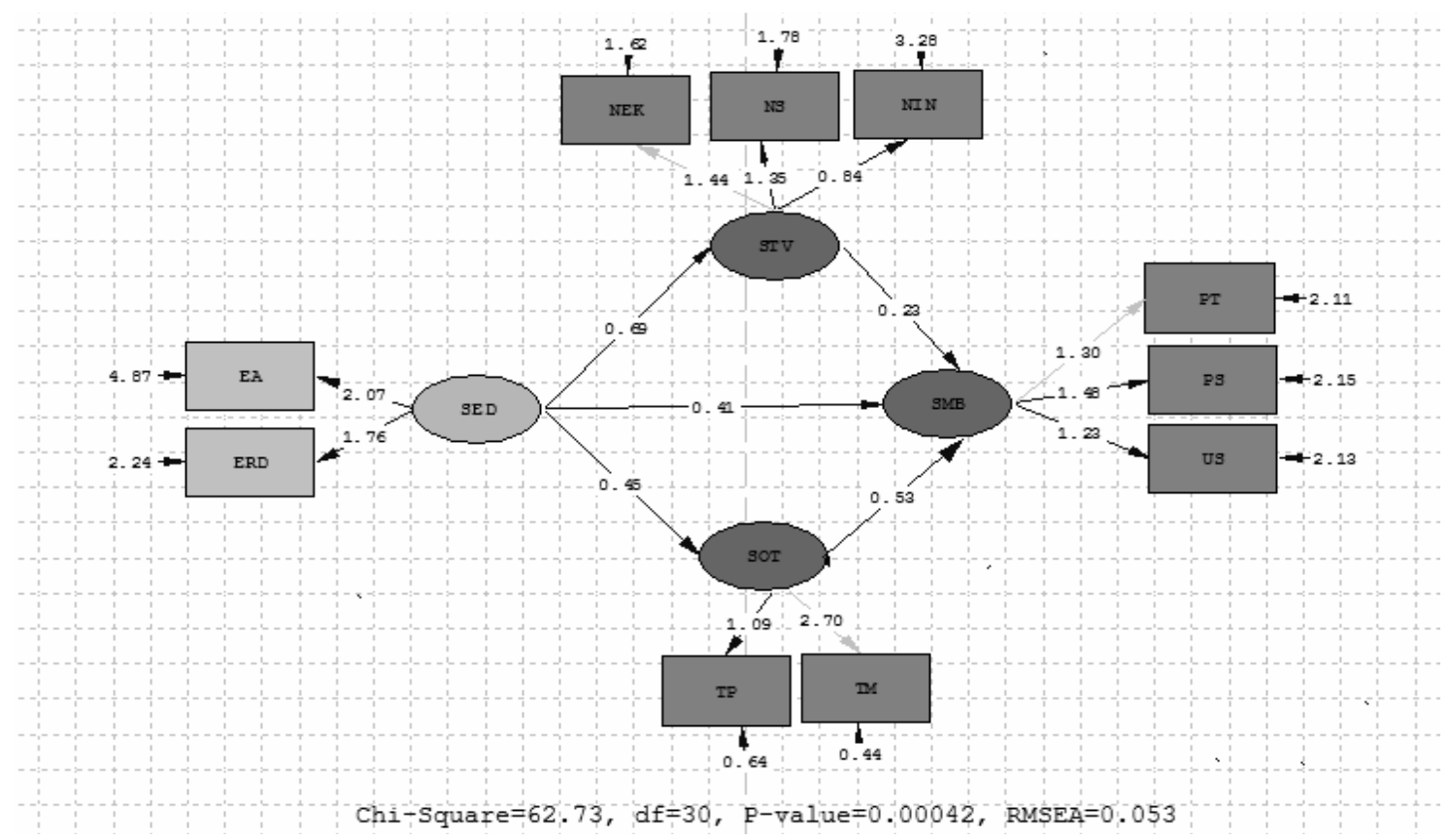

Gambar 2. Koefisien jalur model trisula motivasi berprestasi 
Berdasarkan Gambar 2 tampak bahwa semua variabel yang dimodelkan memiliki hubungan kausal yang bermakna dalam menjelaskan model motivasi berprestasi. Efikasi-diri memiliki faktor loading signifikan terhadap motivasi berprestasi, demikian juga terhadap nilai-tugas dan terhadap orientasi tujuan. Nilai-tugas dan orientasi tujuan juga memiliki faktor loading signifikan terhadap motivasi berprestasi.

Indikator dari tiap-tiap variabel juga memiliki faktor loading yang sigifikan terhadap variabel yang dibentuknya. Pilihan tugas, persistensi, dan usaha, memiliki faktor loading signifikan terhadap konstrak motivasi berprestasi. Nilai guna, nilai spiritual, dan nilai intrinsik, memiliki faktor loading signifikan terhadap konstrak nilai-tugas. Efikasi-diri akademik dan efikasi-diri untuk regulasi-diri memiliki faktor loading signifikan terhadap konstrak efikasi-diri. Tujuan masteri dan tujuan performansi juga memiliki faktor loading yang signifikan terhadap konstrak orientasi tujuan.

\section{Diskusi}

Nilai-tugas mencakup nilai guna atau nilai ekstrinsik, nilai intrinsik, dan nilai spiritual, merupakan faktor-faktor yang menentukan tingginya motivasi berprestasi siswa. Siswa yang meyakini bahwa materi pelajaran dan aktivitas belajar yang dijalaninya dalam kegiatan pembelajaran yang diselenggarakan guru berguna bagi dirinya untuk mendapatkan capaian lain di waktu yang akan datang, baik dalam jangka pendek (untuk menguasai materi atau tugas akademik yang lain, untuk ujian kelulusan) ataupun untuk jangka panjang (dalam kaitannya dengan karir pekerjaan yang diidamkan), merasakan keasyikan ketika menjalani aktivitas pem- belajaran yang diikuti, ditambah lagi adanya keyakinan bahwa aktivitas belajarnya itu mendatangkan ridho/keberkahan dari Tuhan, akan memiliki motivasi berprestasi yang tinggi. Ini sesuai dengan expectacy value model dari Wigfield (1994); Wigfield dan Eccles (2002) bahwa nilaitugas atau seberapa tinggi suatu tugas diyakini mampu memenuhi kebutuhan individu, akan menentukan performansinya dalam melakukan tugas terkait.

Konsep nilai-tugas memiliki kesesuaian dengan konsep motivasi ekstrinsik dan motivasi intrinsik. Keunggulan penggunaan konsep nilai-tugas dibanding motivasi intrinsik dan ekstrinsik sedikitnya ada dua, pertama adanya gambaran yang lebih jelas tentang benefit yang hendak diperoleh terkait dengan tugas yang dikerjakan, dan ke-dua, adanya nilai spiritual yang bagi masyarakat dengan budaya relijius tinggi memiliki arti penting sebagai dasar berperilaku. Nilai-tugas secara spesifik merupakan jawaban atas pertanyaan: apa kegunaan atau manfaat dari materi pelajaran dan aktivitas belajar yang saya lakukan bagiku? Semakin jelas nilai-nilai yang ditemukan individu dalam tugas akademik yang dijalaninya maka performansi akademiknya akan semakin tinggi.

Efikasi-diri merupakan penilaian individu tentang seberapa tinggi kapabilitas dirinya untuk melakukan tugas yang dihadapinya, berkontribusi signifikan terhadap motivasi berprestasi. Ini sejalan dengan hasil-hasil penelitian yang dirangkum Bandura (1997) bahwa siswa dengan efikasi-diri tinggi seringkali mengerahkan usaha lebih banyak, persisten ketika menghadapi kesulitan dalam belajar, menerapkan banyak strategi untuk membuat belajar lebih bermakna.

Dalam kaitan dengan perilaku bermotivasi, Schunk, dkk. (2008) menyatakan bahwa efikasi-diri mempengaruhi akti- 
vitas memilih perilaku prestasi, usaha, dan persisten atau ulet dalam tugas prestasi. Orang dengan efikasi-diri rendah ketika menghadapi suatu tugas sulit dimungkinkan akan menjauhinya, sedang mereka yang yakin memiliki kemampuan akan berpartisipasi dengan senang hati. Khususnya ketika menghadapi kesulitan, siswa dengan efikasi-diri akademik tinggi akan bekerja lebih keras, persisten lebih lama. Penelitian lain (Klassen, Krawchuk, \& Rajani, 2008) melaporkan bahwa dalam studi eksplorasi terhadap prokrastinasi pada 436 mahasiswa ditemukan bahwa efikasi-diri akademik merupakan prediktor yang signifikan bagi prokrastinasi (mahasiswa mengulur-ulur waktu penyelesaian tugas akademik, sehingga tidak bisa lulus tepat waktu). Temuan ini menunjukkan bahwa tingkat prokrastinasi yang tinggi berkaitan dengan lemahnya efikasi-diri akademik pada mahasiswa. Sementara itu, Zimmerman, Bandura, dan Martinez-Pons (1992) melaporkan penelitian yang mereka lakukan terhadap siswa kelas 9 dan 10 menemukan adanya pengaruh efikasi-diri akademik pada prestasi akademik. Mereka juga mengungkapkan bahwa sejumlah studi menunjukkan bahwa siswa dengan efikasi-diri akademik tinggi memperlihatkan persistensi, usaha, dan motivasi intrinsik yang lebih besar dalam performansi akademik mereka.

Temuan ini mendukung hasil-hasil penelitian terdahulu yang dilakukan Graham dan Weiner (1996), Pajares (2003), bahwa efikasi-diri siswa merupakan prediktor yang bagus untuk motivasi akademik dan prestasi akademik. Penelitian ini juga mendukung temuan penelitian Durik, Vida, dan Eccles (2006) yang melibatkan 606 responden siswa kelas $X$ dan kelas XII, menemukan bahwa competence beliefs mampu mepredik motivasi, subjek dengan keyakinan bahwa dirinya kompeten menggunakan waktu lebih panjang untuk mempelajari materi pelajaran dan materi lain yang relevan.

Efikasi-diri tinggi dalam suatu tugas yang cukup sulit mampu menghasilkan keasyikan (motivasi intrinsik) dalam melakukan suatu tugas. Hasil ini sejalan dengan penelitian Bandura (1997) bahwa efikasi-diri memiliki pengaruh penting pada perkembangan motivasi intrinsik. Sesuai teori kognisi sosial, pertumbuhan motivasi intrinsik dibangun melalui reaksi afektif dan mekanisme efikasi-diri. Orang menampilkan motivasi yang menonjol dalam suatu aktivitas di mana mereka merasa memiliki kemampuan dalam melakukan aktivitas tersebut dan dengan itu mereka merasa puas. Meski perilaku tersebut tidak mendapat reward dari lingkungan sosial, perasaan berhasil dalam melaksanakan sutu aktivitas dapat menjadi reward baginya. Standar personal memiliki peranan dalam meningkatnya motivasi terhadap suatu aktivitas atau suatu tugas. Jika seseorang memiliki standar tingkat performansi tertentu yang ingin dicapai, dan akhirnya berhasil mencapai standar performansi tersebut, mereka akan mendapatkan kepuasan. Kepuasan yang diperoleh dari pencapaian tujuan tersebut membangun motivasi intrinsik terhadap tugas atau aktivtas yang dilakukan, hingga terjadinya flow atau hanyut dalam tugas.

Siswa dengan efikasi-diri yang tinggi cenderung menetapkan tujuan-tujuan yang lebih menantang (cukup sulit untuk dicapai), baik tujuan masteri maupun tujuan performansi. Hasil penelitian ini sejalan dengan penelitian Locke dan Latham (1990) bahwa orang dengan efikasi-diri tinggi cenderung menetapkan tujuan yang cukup tinggi untuk diraih, dan efikasi-diri yang tinggi juga berpengaruh penting pada tingginya komitmen untuk mencapai 
tujuan yang telah ditetapkan. Hasil penelitian ini juga sejalan dengan penelitian Potosky dan Ramakrishna (2002) bahwa efikasi-diri berperan signifikan sebagai mediator antara dukungan organisasi untuk melakukan inovasi dengan performansi kerja karyawan. Karyawan yang merasa tidak memiliki kemampuan memadai merasa terancam dan menunjukkan performansi kerja yang rendah. Sebaliknya karyawan dengan efikasi-diri tinggi menunjukkan performansi kerja tinggi.

Hasil penelitian ini agak berbeda dengan penelitian Phillip dan Gully (1997), yang menemukan hasil bahwa efikasi-diri berkorelasi positif dengan orientasi tujuan masteri (learning goal orientation), tetapi berkorelasi negatif dengan orientasi tujuan performansi (performance goal orientation).

Orientasi tujuan berupa sasaransasaran yang dimiliki siswa, terdiri atas tujuan masteri (penguasaan suatu kompetensi) dan tujuan performansi (memperoleh peringkat tinggi dikelas) untuk diujudkan melalui tugas-tugas akademik berkontribusi signifikan terhadap motivasi berprestasi. Ini sejalan dengan hasil penelitian Lee, Sheldon, dan Turban (2003) pada 284 mahasiswa prgram sarjana, bahwa orientasi tujuan berupa tujuan masteri dan tujuan performansi merupakan prediktor yang baik bagi penggunaan strategi-strategi ketika bekerja dalam tugas prestasi.

Temuan ini juga sejalan dengan penelitian Barzegar (2012) pada 260 mahasiswa tahun pertama, bahwa tujuan masteri dan tujuan performansi memberi efek positif terhadap motivasi berupa penerapan strategi kognitif dan strategi metakognitif untuk mewujudkan tujuan yang telah ditetapkan. Mahasiswa yang memiliki tujuan masteri ataupun tujuan performansi yang jelas, memperlihatkan pengerahan usaha lebih banyak, berupa penerapan strategi kognitif dan strategi metakognitif.

Peranan orientasi tujuan bagi motivasi dijelaskan oleh Locke dan Latham (2013) bahwa tujuan merupakan motivasi potensial yang melandasi performansi. Sekali orang berkomitmen dengan tujuan tertentu, mereka akan mencari kepuasan-diri melalui pencapaian tujuan yang telah ditetapkan dengan cara mengerahkan usaha secara intensif. Indikator perilaku pilihan tugas, persistensi, dan pengerahan usaha memiliki faktor loading signifikan terhadap motivasi berprestasi. Hasil ini mengukuhkan konsep yang diajukan Schunk, dkk. (2008) bahwa konstrak motivasi berprestasi terdiri atas empat indikator pilihan tugas (task-choice), persistensi (persistence), usaha (effort), dan prestasi (achievement). Dalam penelitian ini prestasi tidak diambil sebagai indikator motivasi, sebab prestasi merupakan hasil dari perjalanan panjang perilaku berprestasi, dan prestasi dipengaruhi oleh banyak faktor termasuk kemampuan atau kapabilitas diri. Indikator perilaku nilai guna, nilai spiritual, dan nilai intrinsik memiliki faktor loading yang signifikan terhadap konstrak nilai-tugas. Hasil ini mengukuhkan konsep yang diajukan Wigfield dan Eccles (2002) bahwa nilai-tugas terdiri atas nilai-guna (utility value), dan nilai intrinsik (intrinsic value). Nilai capaian (attainment value), dan biaya (cost), tidak dimasukkan dalam konstrak nilai-tugas sebab operasionalisasinya tidak bisa spesifik. Satu nilai lagi yang ditambahkan ke dalam konstrak nilai-tugas yaitu nilai spiritual sebagaimana diajukan Purwanto dan Sutoyo (2007) serta Bell dan Smith (2003).

Dibanding dua indikator perilaku nilai-tugas yang lain (nilai spiritual dan nilai intrinsik) nilai-ekstrinsik atau nilai guna merupakan nilai yang paling lemah. Terhadap hasil ini dapat dijelaskan bahwa 
subjek penelitian, dengan dukungan guru dan orang dewasa lain di lingkungan di mana siswa tinggal, telah mampu mengembangkan nilai spiritual dan nilai intrinsik terkait aktivitas akademik mereka, sehingga nilai spiritual dan nilai intrinsik telah menjadi hal penting yang dapat mereka raih terkait dengan aktivitas akademik mereka. Indikator perilaku efikasi-diri akademik dan efikasi-diri untuk regulasi-diri memiliki faktor loading signifikan terhadap konstrak efikasi-diri. Hasil ini sejalan dengan konsep yang diajukan Bandura (1997) serta Klassen, dkk. (2008), bahwa kontrak efikasi-diri terdiri atas dua indikator yaitu efikasi-diri akademik dan efkasi-diri regulasi diri. Indikator tujuan masteri dan tujuan performansi memiliki faktor loading signifikan terhadap konstrak orientasi tujuan. Hasil ini mengukuhkan konsep yang diajukan Schunk, dkk. (2008), Elliot dan Church (1997), bahwa konstrak orientasi tujuan terdiri atas dua aspek yaitu tujuan masteri dan tujuan performansi.

Dari dua tipe tujuan prestasi sebagai indikator orientasi tujuan tersebut, tujuan performansi memiliki faktor loading lebih besar ketimbang tujuan masteri. Terhadap hasil ini dapat dijelaskan dari dua sisi, pertama bahwa memperoleh pengakuan dari pihak lain merupakan hal penting bagi subjek penelitian. Hal ini sejalan dengan karakteristik budaya masyarakat Indonesia yang memberi nilai tinggi penerimaan sosial. Bahwa seseorang akan merasa berharga terkait dengan sejauh mana ia diterima atau diakui kelompoknya. Kedua, dibanding tujuan masteri, tujuan performansi lebih mudah mengukur ketercapaiannya.

\section{Kesimpulan}

Berdasarkan hasil analisis data dan pembahasan seperti dipaparkan di atas maka dapat disimpulkan bahwa Model Trisula Motivasi Berprestasi, yang terdiri atas nilai-tugas, efikasi-diri, dan orientasi tujuan merupakan model yang andal. Model Trisula Motivasi Berprestasi menjelaskan bahwa, seorang siswa akan memiliki motivasi berprestasi tinggi jika memiliki nilai-tugas tinggi (meyakini bahwa pelajaran dan aktivitas belajarnya merupakan hal berharga yang penting bagi dirinya), dengan efikasi-diri tinggi (siswa meyakini bahwa dirinya memiliki kemampuan akademik dan mampu meregulasi perilakunya untuk mencapai keberhasilan dalam belajar), serta dengan orientasi tujuan tinggi (memiliki sasaran yang jelas untuk dicapai dalam belajarnya).

Motivasi berprestasi siswa berpeluang lebih besar untuk dikembangkan oleh para guru melaui praksis pembelajaran yang diselenggarakan, melalui peningkatan nilai-tugas, efikasi-diri, dan orientasi tujuan. Jika siswa mampu menemukan hal berharga dari kegaiatan belajar dan hasil belajar yang dicapai, jika siswa memiliki pengalaman berharga yang memupuk efikasi-diri dalam belajar, serta didorong untuk menerapkan goal-setting dalam belajar, maka pada saat itulah pembelajaran yang diselenggarakan guru berkontribusi bagi penguasaan materi belajar sekaligus bagi penumbuhan motivasi berprestasi siswa.

\section{Kepustakaan}

Bandura, A. (1997). Self-Efficacy: The Exercise of Control. New York: WH. Freeman.

Bandura, A., \& Schunk, D.H. (1981). Cultivating Competency, Self-Efficacy, and Intrinsic Interest Through Proximal Self-Motivation. Journal of Personality and Social Psychology, 41, 586-589. 
Barzegar, M. (2012). The Relationship Between Goal Orientation and Academic Achievement-The Mediation Role of Self-Regulated Learning Strategies - A Path Analysis. International Conference on Management, Humanity and Economics, August 11-12, 2012, Phuket Thailand.

Bell, A. H., \& Smith, D. M. (2003). Motivating Yourself For Achievement. New Jersey: Prentice Hall.

Durik, A. M., Vida, M., \& Eccles, J. S. (2006). Task Values and Ability Beliefs as Predictors of High School Literacy Choices: A Developmental Analysis. Journal of Educational Psychology, 98, 382-393.

Elliot, A. J., \& Church, M. M. (1997). A Hierarchical Model of Approach and Avoidance Achievement Motivation. Journal of Personality and Social Psycho$\log y, 72,218-232$.

Klassen, R. M., Krawchuk, L. L., \& Rajani, S. (2008). Academic Procrastination of Undergraduate: Low self-efficacy to self-regulate predicts higher level of procrastination. Contemporary Educational Psychology, 33, 915-931.

Locke, E. A., \& Latham, G. P. (1990). A Theory of Goal Setting and Task Performance. New York: Printice Hall.

Locke, E. A., \& Latham, G. P. (2013). New Developments in Goal Setting and Task Performance. New York: Routledge.

Nicholls, J. G. (1984). Achievement Motivation: Conception of Ability, Subjective Experience, Task Choice, and Performance. Psychological Review, 91, 328-346.

Pintrich, P. R., \& De Groot, E. V. (1990). Motivational and Self-Regulated Learning Component of Classroom
Academic Performance. Journal of Educational Psychology. 82(1), 33-40.

Pintrich, P. R., Smith, D. A. F., Garcia, T., \& McKeachie, W. J. (1991). A Manual for the Use of the Motivated Strategies for Learning Questionaire (MSLQ). Eric Institute of Education Science.

Potosky, D., \& Ramakrishna, H. V. (2002). The moderating role of updating climate perceptions in the relationship between goal orientation, self-effi cacy, and job performance. Human Performance, 15 , 275 - 297.

Purwanto, E., \& Sutoyo, A. (2008). Peningkatan Motivasi Berprestasi Melalui Pelatihan Atribusi Kausal SpiritualQur'ani. Laporan Penelitian. Semarang: LP2M Universitas Negeri Semarang.

Schunk, D. H. (1981). Modeling and Attributional Effect on Children's Achievement: A Self-Efficacy Analysis. Journal of Educational Psychology, 73, 93-105.

Schunk, D. H., Pintrich, P. R., \& Meece, J. L. (2008). Motivation in Education, Theory, Research, and Applications. Third Edition. New Jersey: Pearson Educatuon, Inc.

Slavin, R. E. (2009). Educational Psychology, Theory Into Practice. New Jersey: Prentice Hall Inc.

Tobias, S. (1995). Motivasit And Metacognitive Word Knowledge. Journal of Educational Psychology, 87(3), 399-405.

Wigfield, A., \& Eccles, J. S. (2002). Development of Achievement Motivation. San Diego, CA: Academic Press.

Zimmerman, B. J., \& Kitsantas, A. (2002). Acquiring Writing Revision and Selfregulatory Skill Through Observation and Emultion. Journal of Educational Psychology, 94(4), 660-668. 